\title{
OVERCOMING A CRISIS OF IMAGINATION: THE UNIVERSITY AND ITS FUTURES
}

\author{
Jakub Krzeski*
}

Review of IZAK, Michał; KOSTERA, Monika; ZAWADZKI, Michał. (Eds.). The future of university education. Basingstoke: Palgrave Macmillan, 2017.

To say that University is in crisis is to say something trivial. Narratives such as Mode 2 (GIBBONS; NOWOTNY; SCOTT, 2001; HESSELS; LENTE, 2008), Triple helix (RANGA; ETZKOWITZ, 2013), academic capitalism (SLAUGHTER; RHOADES, 2004a; CANTWELL; KAUPPINEN, 2014) or enterprise university (MARGINSON; CONSIDINE, 2000) all point to the fact, that due to the external pressure something profoundly changed in the way universities function and knowledge is produced. Academic endeavour as we once knew, might very well no longer exist. The sheer scale of changes that took place in recent years has forced an increasing number of scholars to express the need for systematic higher education research, which will not be limited only to a descriptive level but will occupy the critical position as well (WILLIAMS, 2016). Critical also in the sense of intervention in a crisis to show possible scenarios of overcoming it (KOSELLECK, 2006).

One of the places that were created to popularize this type of reflection is the Palgrave Critical University Studies series. Despite the fact that it exists only since 2016, so far eleven books have been published in the series. However, a quick look at it will suffice to realize that critical research on higher education cannot even be viewed as a young discipline. The wide range of topics, ranging

\footnotetext{
"Ph.D. candidate at the Institute of Philosophy of Adam Mickiewicz University in Poznań (Poland), editor of peer-reviewed journal Praktyka Teoretyczna (Theoretical Practice) and translator. He graduated from College of Inter-Faculty Individual Studies in the Humanities of Warsaw University, where he studied philosophy and cultural studies. He is currently working on a doctoral thesis on the academic capitalism and center/periphery divide in the global knowledge production.
} 
from gender or class to new public management in higher education, as well as the diversity of theoretical inspirations and the research methods themselves, all indicate that what are we dealing with, are in fact the very first attempts to consolidate such a field. Based on these efforts it is still difficult to predict the direction of further discipline development. If something connects this wide range of perspectives, it is instead a "critical agenda," as the editors of the series call it, and hence a set of common questions or challenges that must be addressed. Therefore, the primary concern is the possibility of breaking with the present structures of power and domination and conceiving in their place a more just or self-governing way of practicing science and education.

The Future of University Education, edited by Michał Izak, Monika Kostera, and Michał Zawadzki, published in the Palgrave series, is an excellent example of such diversity in the field of critical research on higher education. It is divided into four parts and consists of seventeen chapters, written by scholars from various social sciences and humanities fields. The first section is devoted to the task of dissecting the status quo and therefore deals with such issues and topics as academic freedom, subsumption of higher education under capital, the ideology of performance management and audit culture. The second part puts the debate on the future university in the broader context, asking about the importance of such notions as homo oeconomicus, social change or even participatory architecture to this discussion. The third one deals with the two most fundamental academic activities, that is, research and teaching. Although much more attention is given to the former, this section still addresses such vital issues as "Mclearning" and necessity of teaching and research integrity. Finally, the last one is written in a speculative manner as it consists of different scenarios, some of them optimistic and the others more skeptical, for future of academic endeavour.

All chapters differ from one another not only regarding the subject but even in the literary style. Some of them are more academic and rely heavily on conducted research, as in the case of Michał Zawadzki's chapter on the young Polish academics under performance management pressure, the others are much more poetic and are not afraid to use the literary fiction to make a point. 
Although such lack of coherence may at first surprise readers, in fact, it was intended. As editors conclude in the final chapter: "what we hope that this volume has achieved is having taken the reader for a radically imaginative journey exploring the post-capitalist alternatives to the currently dominating models of University (as an institution) and educational process" (IZAK; KOSTERA; ZAWADZKI 2017, p. 330). Instead of establishing one critical perspective, The Future of University Education takes, therefore, a different approach. It is a record of various imaginative exercises that are needed to overcome the contemporary crisis of imagination, inability to think beyond the current state of affairs (Barnett 2013).

\section{A CRISIS OF IMAGINATION}

Higher education research is characterized by a considerable degree of interdisciplinarity (TEICHLER, 2015), but without a doubt, the main subject of its interest is the functioning of the university as an institution. The most appropriate method for such defined task is, of course, empirical research. But as we have already emphasized, the voices on the necessity of establishing a parallel discipline that will be a response to the shortcomings of existing research are slowly emerging (BARNETT, 2016b). Such a field - or critical university studies, as we may call it - for which the proper subject of the investigation will not be limited only to empirical realizations, has to focus above all on the university as a particular idea, for which there is long and productive tradition exceeding current institutional form. Thus understood, the field is not focused on analysing the current state of affairs but perceives the university as a reality that goes beyond its present form. Critical university studies require conceptual work and not merely empirical research.

Such a task of critical approach would consist in opposing a position that perhaps in most adequate form was introduced by Bill Readings in his seminal book The University in Ruins (1997). For Readings, the contemporary crisis goes so far that it reaches ontological foundations of the university. It lasts, despite the disappearance of the very purpose for which it was created. The continuous 
processes of globalization, the growing importance of transnational corporations, and finally the depletion of the form of a nation-state have undermined the role of the modern university, which was responsible for keeping custody over national culture. Moreover, the currently perceptible subordination of higher education institutions to the regime of "excellence" makes this mission impossible to perform within the university itself.

Thus, according to Readings, the only thing that remains for the members of the academic community is to get used to living among the title ruins with the consciousness of the post-historical existence of the university. Students and academic staff are reliant on cultivating a "community of dissensus," which no longer claims to pursue the same tasks as its predecessor. Such a position, mainly based on the belief at the end of university's historical existence, is opposed by critical scholars, including contributors to The Future of University Education. It is possible by attributing the critical studies the task of seeking the causative factors responsible for shaping its development, but also, in the spirit of Deleuze and Guattari (1993), creating new concepts which, by empowering the imagination, will help in directing these changes.

\section{CONNECTING PARS DESTRUENS AND PARS CONSTRUENS}

Our understanding of the university must take into account the processual nature of the University's reality and coexistence with its outside, through which it is transformed not only as an institution but also as an idea. Only by embedding the actualization in the chain of the transformation of ideas, we will be able to see empirical manifestation only as one of many university's ephemeral forms, and thus perceive the university's ability to make subsequent, undetermined transformations.

That is why critical university studies, although they might be considered too syncretic, frequently combining concepts with seemingly conflicted philosophical languages, aim to achieve a defined goal: to show the university in its potentiality or being towards (BARNETT, 2011). Barnett, pathing the way for other critical scholars, thus breaks with the understanding of the idea as eternal 
and concealing a predetermined truth that would make one look at the changes of the university regarding the failure or success of its implementation in empirical manifestations. Concepts such as knowledge or the university exist precisely in their becoming, which can be captured only by noticing the economic, political or social context of its existence. Research conducted in this spirit, according to the postulate of Theodor Adorno, would instead reject a rigid division into philosophy and sociology (ADORNO, 2008; BARNETT, 2016a).

Such a perspective, stemming from Barnett's work, is of such importance, precisely because it draws a project of thinking about the university in which its future holds its centre. By trying to understand the logic of university transformations, our attention is focused on the scenarios of its further development or directions of further evolution. Thus, interventions made in the university crisis can, instead of postulating the restoration of the long gone past, focus on the possibilities that this crisis opens up.

Unfortunately, all too often the attempts at understanding the direction of university transformation are imprisoned in the horizon of the past. By not seeing that the broader socio-economic conditions that formed the basis for the form of existence of a given academic community have ceased, such attempts are not able to recognize that the given implementation of the university's idea has passed with them as well. As long as the criticism is limited to this horizon, as it limits itself to the negative dimension of the critique, that is pars destruent, it will not be able to create pars construens, that is an indispensable point of criticism in which a new project is being drawn upon the ground of the questioned state of affairs.

\section{BEYOND THE INDIVIDUAL IMAGINATION}

Therefore, The Future of University Education is at its best when trying to put the concepts into motion in a promising way, as well as when it gives hope for bolder and more adequate to the broader socio-economic environment scenarios of university transformations. Unfortunately, this does not occur in case of each chapter. Part of the blame bears the construction of the book itself, which 
artificially separates sections and thus disintegrate critical approach. This division is most evident in the case of part one and part four. While the former deals with the negative aspect of critique by dissecting current state of affair, the latter is concerned with the future itself. In effect, what should be integral, is in fact separated. Scenarios for the future university are not based on material conditions of their realization or in the worst scenario, the present state of affairs is treated as something given and should not be contested. Such is the case, for example, with Todd Hannula's chapter, "A Curious and Collaborative Future," in which author shows the inability of the contemporary universities to adapt to a rapidly changing labor market and its needs. The perspective is thus shifted. It is no longer our task to realize the future of the post-capitalist university, but instead, universities themselves have to reflect on their place in the ever-changing world. There is a reasonable doubt to what extent we can call such an attempt genuinely critical.

Thankfully some authors failed to fit in these frames and were able to connect both indispensable moments of critique - pars destruens with pars construens. The example of such chapter is a contribution by Krystian Szadkowski, "The University of the Common: Beyond the Contradictions of Higher Education Subsumed under Capital." In his Marxist-oriented perspective, Szadkowski attempts to ground possibility for the future university precisely in the contemporary material conditions of possibility. For this purpose, he differentiates two types of contradictions of the contemporary higher education system: the apparent and the real ones. If the former describes the dialectical relation between the two poles, dissolution of the latter can lead to the true autonomy of one of its component. For example, such real contradiction in case of the university is one between the common and the capital. Therefore this chapter can be read as an example of the integral critical approach. Going beyond capitalism, academic capitalism included, requires an understanding of such real contradictions inherent in the material reality. This chapter is worth reading together with a contribution by Roger Hallam, "Escape from the Neo-Liberal Higher Education Prison: A Proposal for a New Communist University." Not only 
because both authors share a similar perspective, but also because of the former shed some light on high points and weaknesses of the latter.

Hallam's text is "partially rooted in the traditional analogue utopian communist tradition while at the same time grappling with the expanding potentialities of the digital transformation" (HALLAM, 2017, p. 262). Therefore it is written in the very spirit of connecting bold visions of the future with material conditions of its realization. Although the chapter is written under the influence of accelerationist's vision of post-capitalist future (MASON, 2015; SRNICEK; WILLIAMS, 2015) and deals with the possibility of emancipation embedded in technological changes, it can also be read from the perspective of the theories of the commons (DE ANGELIS, 2004; DE ANGELIS, 2017). After all contemporary circulation of knowledge and its digitalization very much resemble the governing of the commons as well as the process of its appropriation. In case of academic publishing, enclosures by capitalist publishers such as Elsevier. It's a shame that this contradiction between the common and capital is hardly present in his otherwise imaginative and engaging chapter. The conflictual nature of the processes described by Hallam is especially visible from the peripheral position, where access to central circuits of knowledge is vital for the possibility of participation and presence on the international level. Essentially, this is not a coincidence that Alexandra Elbakyan, the creator of Sci-Hub, online tool for bypassing publisher paywall and accessing articles and books, is a Kazakstanian Ph.D. The story of Sci-Hub should be instructive for us. Its slogan, "To remove all barriers in the way of science," points after all directly at capital as the main obstacle. And we can be sure that capital will not go down without a fight.

I find those two chapters most appealing not only because of sharing similar theoretical sympathy with authors but above all because they point to something crucial. The necessity of going beyond the individualistic approach, one where the individual is posed as something ontologically primary. To break with higher education subsumed under capital, we have to collectively challenge this perspective and recognize it as a backbone of academic capitalism. This is also why critical studies of higher education need a break with the individualistically understood imagination, which takes the form of an act of 
creation of an individualized subject. We must begin to understand imagination differently, as something transindividual, shaped by the relations in which we enter with each other. The imagination interpreted in such a way compels us to look for new ways of collective management of our commons and effective struggle against its appropriation. Although it does not contain any promise in itself, it is precisely this mechanism that allows us to increase the collective power and ability to act. We need this as never before because we are still far away from creating a critical mass necessary to make any difference and realize scenario for the future university. Therefore, if you are not interested in a question "what the universities are for?" but rather "what they can be for?", The Future of University Education will be an engaging read.

\section{REFERENCES}

ADORNO, T. Lectures on negative dialectics. Cambridge: Polity, 2008.

BARNETT, R. Being a university. Abingdon: Routledge, 2011.

BARNETT, R. Imagining the university. Abingdon: Routledge, 2013.

BARNETT, R. "Constructing the university: towards a social philosophy of higher education." Educational Philosophy and Theory, v. 49, n. 1, 2016a, p. 78-88.

BARNETT, R. Understanding the university: institution, idea, possibilities. Abingdon: Routledge, 2016b.

DE ANGELIS, M. "Separating the doing from the deed: capital and the continuous character of enclosures." Historical Materialism, v. 12, 2004, p.57-87.

DE ANGELIS, M. Omnia sunt communia: on the commons and the transformation to postcapitalism. London: Zed Books, 2017.

DELEUZE, G.; GUATTARI, F. What is Philosophy? London: Verso, 1993.

HALLAM, R. "Escape from the neo-liberal higher education prison: a proposal for a new communist university." In: IZAK, Michał; KOSTERA, Monika; ZAWADZKI, Michał (Eds.) The future of university education. Basingstoke: Palgrave Macmillan, 2017. 
HESSELS, L., VAN LENTE, H. "Re-thinking new knowledge production: A literature review and a research agenda." Research Policy, v. 37, n. 4, 2008, p.740-760.

KAUPPINEN, I.; CANTWELL, B (Eds.). Academic capitalism in the age of globalization. Baltimore: John Hopkins University Press, 2014.

KOSELLECK, R. "Crisis." Trans. M. Richter. Journal of the History of Ideas, v.67, n. 2, 2006, p. 357-400.

MARGINSON, S.; CONSIDINE M. The enterprise university: power, governance, and reinvention in Australia. Cambridge: Press Syndicate of the University of Cambridge, 2000.

MASON, P. Post-capitalism: a guide to our future. London: Allen Lane, 2015.

NOWOTNY, H.; SCOTT, P.; GIBBONS, Michael. Re-thinking science: knowledge and the public in an age of uncertainty. Cambridge: Polity Press, 2001.

RANGA, M., ETZKOWITZ, H. "Triple helix systems: an analytical framework for innovation policy and practice in the knowledge society." Industry and Higher Education, v. 27, n. 4, 2013, p. 237-262.

READINGS, B. The university in ruins. Cambridge, MA: Harvard, 1997.

SLAUGHTER, S.; RHOADES, G. Academic capitalism and the new economy: markets, state and higher education. Baltimore, 2004.

SRNICEK, N.; WILLIAMS, A. Inventing the future: post-capitalism and the world without work. London: Verso, 2015.

TEICHLER, U. "Higher education research in Europe." In: CURAJ, A.; MATEI, L.; PRICOPIE, R.; SALMI, J.; SCOTT, P. (Eds). The European higher education area. Springer, 2015. p. 815-847.

WILLIAMS, J. J. "The need for critical university studies." In: HUNTER, G.; MOHAMED, F. A New Deal for the Humanities. Rutgers University Press, 2016. p. 145-159.

Recebido em: 16/11/2017

Aprovado em: 14/12/2017 